\title{
Medicinal plants with mosquitoes repellent activity: a systematic review
}

\author{
Plantas medicinais com atividade repelente de mosquitos: uma revisão sistemática \\ Plantas medicinales con actividad repelente de mosquitos: una revisión sistemática
}

Received: 11/30/2021 | Reviewed: 12/09/2021 | Accept: 12/17/2021| Published: 01/01/2022

\author{
Anderson Ribeiro dos Santos \\ ORCID: https://orcid.org/0000-0003-3868-3380 \\ Federal University of Sergipe, Brazil \\ E-mail: andersonfarmacia@yahoo.com.br \\ Alexia Mota Santos \\ ORCID: https://orcid.org/0000-0003-2715-6745 \\ Federal University of Sergipe, Brazil \\ E-mail: alexiamotafarm@gmail.com \\ Fernando Henrique Oliveira de Almeida \\ ORCID: https://orcid.org/0000-0002-1728-9598 \\ Federal University of Sergipe, Brazil \\ E-mail: fernandoalmeidafitofarm@gmail.com \\ Vinícius Freitas Arcieri de Medeiros \\ ORCID: https://orcid.org/0000-0003-0561-2420 \\ Federal University of Sergipe, Brazil \\ E-mail: vfreitas12@gmail.com \\ Saulo Santos Matos \\ ORCID: https://orcid.org/0000-0002-6780-4236 \\ Federal University of Sergipe, Brazil \\ E-mail: saulosm95@gmail.com \\ Thaís Feitoza de Carvalho \\ ORCID: https://orcid.org/0000-0001-7381-4791 \\ Federal University of Sergipe, Brazil \\ E-mail: thaisfeitoza14@gmail.com \\ Carlos Adriano Santos Souza \\ ORCID: https://orcid.org/0000-0002-7913-2510 \\ Federal University of Sergipe, Brazil \\ E-mail: carlos.953@gmail.com \\ Tamires Cardoso Lima \\ ORCID: https://orcid.org/0000-0001-6200-649X \\ Federal University of Sergipe, Brazil \\ E-mail: tamires.c187@gmail.com \\ Francilene Amaral da Silva \\ ORCID: https://orcid.org/0000-0001-6729-2843 \\ Federal University of Sergipe, Brazil \\ E-mail: farmsilva@hotmail.com
}

\begin{abstract}
Repellents are important allies in trying to prevent diseases transmitted by mosquito bites. Plants have been a source of various repellents and insecticides because they have a large reservoir of bioactive substances, in addition, their products have already been tested and are gaining space in research as a low-cost and easy-access alternative. A systematic review was carried out in the databases, Science Direct, Scielo, SciFinder, Springer, PubMed / Medline, Scopus and Web of Science, evaluated by three reviewers. Titles, abstracts and articles were analyzed in full in English, Spanish and Portuguese. To identify the articles, the following descriptors from the Medical Subject Headings (MeSH) were used: "insect repellents", "essential oils", "plants extract", "repellent activity", mosquitoes and plants. The bibliographic search resulted in 2274 records. Of these, 27 abstracts were considered potentially relevant, and at the end of the selection, 17 articles were included in their entirety. It was found that medicinal plants showed repellent activity against various species of mosquitoes, however due to the little standardization of the methodologies used and the products obtained it is necessary to develop standardized methods to guarantee the quality and reproducibility of clinical trials with medicinal plants.
\end{abstract}

Keywords: Medicinal plants; Essential oils; Mosquitoes; Repellent activity; Standardization; Aedes aegypti.

\section{Resumo}

Os repelentes são aliados importantes na tentativa de prevenir doenças transmitidas por picadas de mosquitos. As plantas têm sido fonte de diversos repelentes e inseticidas por apresentarem um grande reservatório de substâncias 
bioativas, além disso, seus produtos já foram testados e vêm ganhando espaço em pesquisas como alternativa de baixo custo e fácil acesso. Foi realizada revisão sistemática nas bases de dados Science Direct, Scielo, SciFinder, Springer, PubMed / Medline, Scopus e Web of Science, avaliadas por três revisores. Títulos, resumos e Artigos foram analisados na íntegra nos idiomas inglês, espanhol e português. Para a identificação dos artigos, foram utilizados os seguintes descritores do Medical Subject Headings (MeSH): "repelentes de insetos", "óleos essenciais", "extrato de plantas", "atividade repelente", mosquitos e plantas. A busca bibliográfica resultou em 2274 registros. Destes, 27 resumos foram considerados potencialmente relevantes e, ao final da seleção, 17 artigos foram incluídos na íntegra. Verificou-se que as plantas medicinais apresentaram atividade repelente contra várias espécies de mosquitos, porém devido à pouca padronização das metodologias utilizadas e dos produtos obtidos é necessário o desenvolvimento de métodos padronizados que garantam a qualidade e reprodutibilidade dos ensaios clínicos com plantas medicinais.

Palavras-chave: Plantas medicinais, Óleos essenciais; Mosquitos; Atividade repelente; Padronização; Aedes aegypti.

\section{Resumen}

Los repelentes son aliados importantes para tratar de prevenir enfermedades transmitidas por picaduras de mosquitos. Las plantas han sido fuente de diversos repelentes e insecticidas porque cuentan con un gran reservorio de sustancias bioactivas, además, sus productos ya han sido probados y están ganando espacio en la investigación como alternativa de bajo costo y fácil acceso. Se realizó una revisión sistemática en las bases de datos Science Direct, Scielo, SciFinder, Springer, PubMed / Medline, Scopus y Web of Science, evaluadas por tres revisores. Los títulos, resúmenes y artículos fueron analizados íntegramente en inglés, español y portugués. Para identificar los artículos se utilizaron los siguientes descriptores de Medical Subject Headings (MeSH): "repelentes de insectos", "aceites esenciales", "extracto vegetal", "actividad repelente", mosquitos y plantas. La búsqueda bibliográfica dio como resultado 2274 registros. De estos, 27 resúmenes se consideraron potencialmente relevantes y, al final de la selección, se incluyeron 17 artículos completos. Se encontró que las plantas medicinales mostraron actividad repelente contra varias especies de mosquitos, pero debido a la falta de estandarización de las metodologías utilizadas y los productos obtenidos, es necesario desarrollar métodos estandarizados para asegurar la calidad y reproducibilidad de los ensayos clínicos con plantas medicinales.

Palabras clave: Plantas medicinales; Aceites esenciales; Mosquitos; Actividad repelente; Estandarización; Aedes aegypti.

\section{Introduction}

Mosquitoes are considered a serious public health problem due to serving as vectors for many important pathological conditions as well as inflicting significant discomfort through bites (Rueda, 2008; Ali et al., 2012). There are approximately 3500 mosquito species throughout the world, the majority of which are found in tropical and subtropical regions. However, only $10 \%$ have medical and veterinary relevance (Reiter, 2001). The most prevalent mosquitoes that act as vectors of human diseases are Aedes (Chikungunya, Zika, Dengue, and Yellow fever), Anopheles (malaria and filariasis), and Culex (Japanese encephalitis, West Nile virus, and filariasis) (Ghosh et al., 2012; Naseem et al., 2016). Recently, the Zika virus is creating damage in several parts of the world, including Brazil, Africa, Pacific Island, and Southeast Asia. According to Pan American Health Organization (PAHO), more than 40 countries or territories in the Americas recorded an epidemic of Zika virus in 2015-2016, with over 500,000 Zika suspected and confirmed cases (WHO, 2016).

Current and past strategies for mosquito control are based on synthetic insecticides, such as dichlorodiphenyltrichloroethane (DDT), temephos, and malathion. Although chemical agents have been successfully utilized in mosquitoes control during the last decades, the continuous use of these agents has resulted in the development of resistance, environmental impacts, and undesirable effects on non-target organisms, including humans (Deletre et al., 2019). All these factors have created a need for new biodegradable and renewable alternative insecticides. In this context, the use of plantderived natural products for vector control has various attractive characteristics, including biodegradability, availability at affordable prices, smaller toxicity, and broad-spectrum target-specific activities against different mosquito species (Ghosh et al., 2012; Varun et al., 2013; Wilke \& Marrelli, 2015).

Essential oils, also known as essences, volatile oils, or etheric oils, are defined as complex mixtures of several volatile and lipophilic compounds, being constituted principally by terpenes (mono and sesquiterpenes) and phenylpropanoids 
(Guenther, 1972; Sangwan et al., 2001). A great number of essential oils extracted from different aromatic plants has shown great potential for pest management, since these oils possess high repellency against several arthropod species (Geetha \& Roy, 2014). As an example, we can highlight the citronella (Cymbopogon nardus) essential oil, one of the most common essential oils in mosquito repellent patents (Pohlit et al., 2011). In the United States, the U.S. Environmental Agency (U.S. EPA), responsible for repellent products regulation, has recognized and registered citronella oil as an insect repellent ingredient for human applications since 1948 (EPA, 1999). Given the above, we present here a systematic review of clinical articles on medicinal plants with mosquito repellent activity.

\section{Methodology}

Protocol of this study was registered in the International Prospective Register of Systematic Reviews (PROSPERO), an open access database of systematic reviews administered at the Centre of Reviews and Dissemination, University of York, UK PROSPERO under number CRD42017070923 (BOOTH et al., 2012).

\section{Article search strategy}

The search strategy was carried out based on studies available in scientific literature until August 2021. There was no initial time limit. The bibliographic literature search was conducted in different scientific databases, including Science Direct, Scielo, SciFinder, Springer, PubMed/Medline, Scopus, and Web of Science. In addition, a manual search was performed by analyzing the references of the included articles. The literature search was performed in English, Spanish and Portuguese. For identification of articles, the following descriptors of the Medical Subject Headings (MeSH) were used: "insect repellents", "essential oils", "plants extract", "repellent activity", "mosquitoes" and "plants". The descriptors were adapted to each database and combined through the Boolean operators (OR, AND, and NOT).

The titles and abstracts were evaluated according to predefined inclusion criteria to determine the relevance of this topic: clinical trials evaluating the use of medicinal plants as mosquito repellents; clinical trials with medicinal plant essential oils and clinical trials with plant products. The exclusion criteria were comments, editorials, articles not published in Portuguese, Spanish, and English, and articles not available in full.

Initially, the records were exported to Mendeley program 1.16.3 @ C. Data extraction and initial assessment of the relevant records followed by the abstracts and full text was conducted by two independent reviewers (ARS and AMS). Then, selection divergences were resolved by a third reviewer (CASS) and consensus-building. After a consensus meeting, articles that were not within the scope of this review were excluded. Cohen's Kappa statistic was used to measure reliability among the evaluators (Mchugh, 2012).

\section{Evaluation of repellent activity and repellent product quality}

To evaluate interventions with medicinal plants, the following criteria were used: randomization, blinding of the participants (double-blind), description of the methods of randomization, and report of losses and exclusions after randomization. The used features to evaluate the quality of the products tested in the clinical trials were: characteristics of the medicinal plant; botanical identification; plant parts; type of product (fresh, dry, or extracts) and standardization of products (dose of active constituents / biomarkers) (Gagnier et al., 2006).

\section{Quality of clinical trials of repellent activity with medicinal plants}

This evaluation was performed according to the Main Items for Reporting Systematic Reviews and Meta-analyzes 
(PRISMA). This statement provides essential information on the methodology and development of systematic reviews, as follows: terminology, research question formulation, study identification and data mining, study quality and results of publication (Moher et al., 2009).

\section{Results}

Initially, 2,274 records were found in the databases used. Of these, 27 abstracts were considered potentially relevant and, at the end of the selection, 17 articles were included in this systematic review according to the adopted inclusion and exclusion criteria (Figure 1). Most studies came from India 23\% ( $\mathrm{n}=4)$, followed by Thailand $17 \%(\mathrm{n}=3)$, Colombia, Johannesburg, Ethiopia, Nigeria, Nepal, Malaysia, Bolivia, Benin, USA, Guatemala, and Peru.

Regarding the design of clinical trials, $71 \%(n=12)$ were not randomized and 29\% $(n=5)$ were randomized Table 1. The control groups present in the research were volunteers who did not apply any odorous or repellent substance on the arm. The mean duration of the study was $(\mu)=1.3$ months with a standard deviation of $(\sigma)=0.9$ Table 2 .

As for the methodology of clinical trials, the main negative points were the lack of randomization, blinding of the participants, and no description of losses and exclusions Table 1. The main products used were essential oil with 59\% $(\mathrm{n}=10)$, followed by crude extract with $29 \%(\mathrm{n}=5)$ Table 3 . The study included eighteen species of vectors, with an emphasis on the species Aedes aegypti, which was present in $28 \%$ of the analyzed studies Table 1.

The leaf was the main part of the plant used, $47 \%(n=8)$ in the preparations of repellents and the most used pharmaceutical form was a solution present in $47 \%(\mathrm{n}=8)$ of the studies. Among the 17 studies, only two standardized their products according to the substance/markers present Table 3. Furthermore, only 6\% $(\mathrm{n}=1)$ of the studies reported not having achieved significant findings, while $94 \%(\mathrm{n}=16)$ of the studies speculated positive repercussions regarding the efficacy of the medicinal plant tested.

Concerning the technological quality of clinical trials involving medicinal plants with repellent activity, the main absences verified were: characterization of the medicinal plant $(64.70 \%)$, standardization of products $(94.11 \%)$, concentration of used extraction solvent $(52,94 \%)$, and qualitative and purity tests (100\%) Table 3. 
Research, Society and Development, v. 11, n. 1, e2611124142, 2022

(CC BY 4.0) | ISSN 2525-3409 | DOI: http://dx.doi.org/10.33448/rsd-v11i1.24142

Figure 1 - Flowchart of the Selection Process of Included Studies.

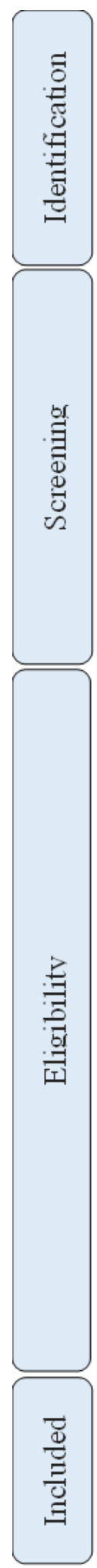

Number of records identified in the survey $(n=2274)$

Number of records indexed in more than one database: $(n=905)$

Total number of records without duplicates $(n=1369)$

Exclusions based on studies that were not clinical trials and did not assess herbal repellent activity $(\mathrm{n}=1342)$

Total abstracts evaluated $(n=27)$

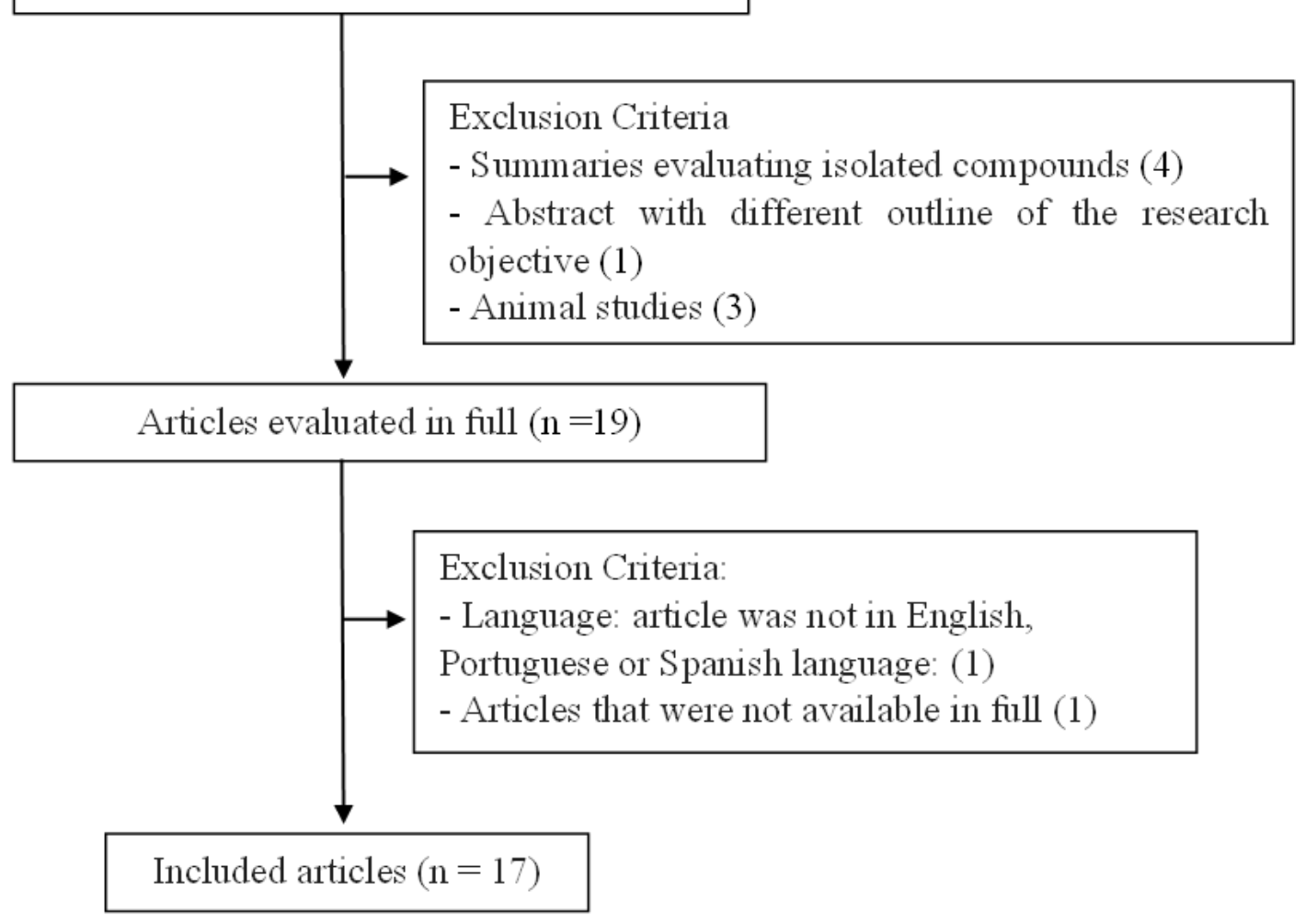

Source: Own Authorship. 
Table 1. Evaluation of the clinical trials methodology (randomization, blinding, description of losses and exclusions).

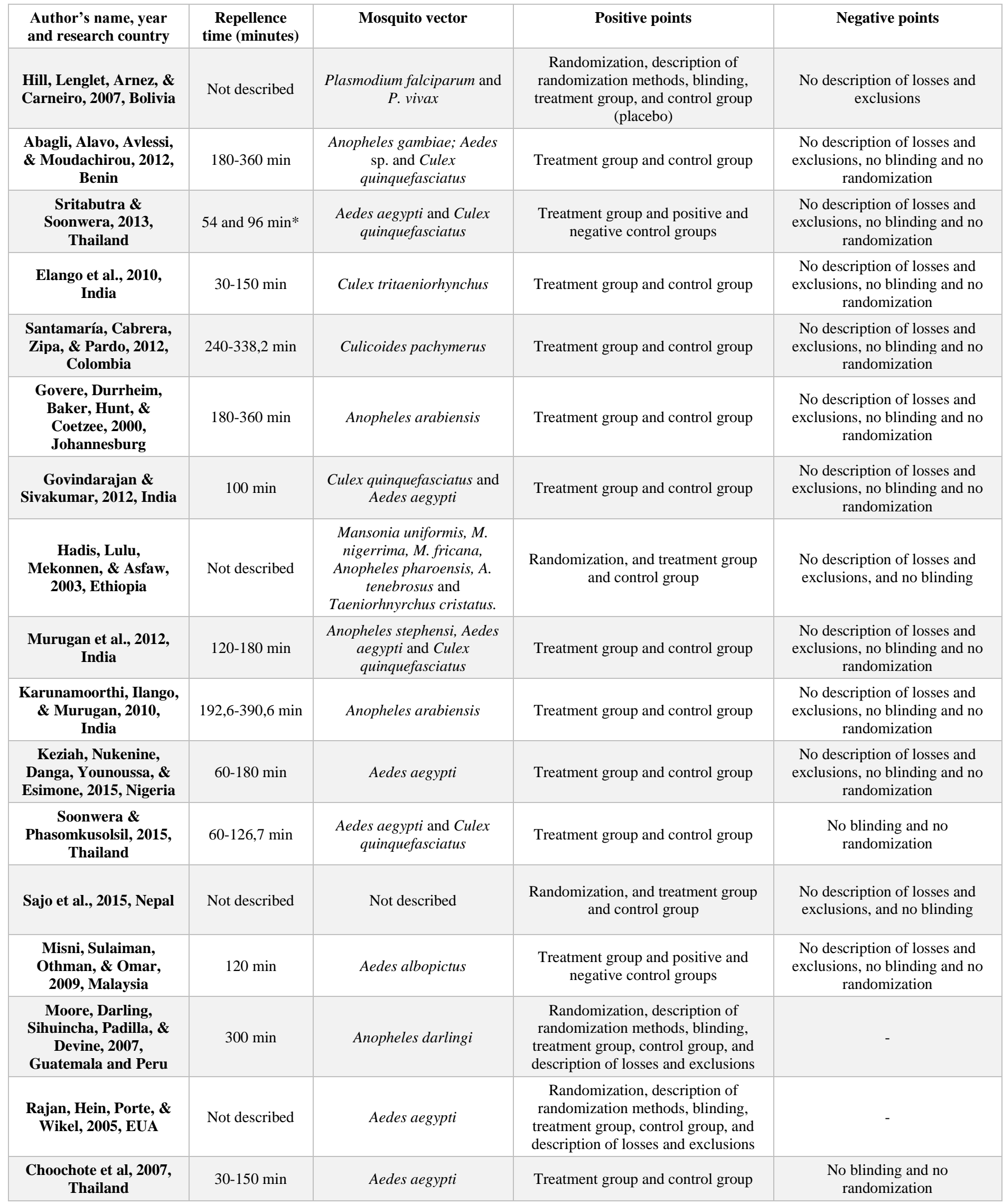

*Ae. Aegypti. Source: Own Authorship. 
Table 2. General characteristics of the studies included in the systematic review.

\begin{tabular}{|c|c|c|}
\hline Author's name, year and research country & Study duration & Research limitations \\
\hline Hill, Lenglet, Arnez, \& Carneiro, 2007, Bolivia & 7 months & Not described \\
\hline Abagli, Alavo, Avlessi, \& Moudachirou, 2012, Benin & 4 months & Not described \\
\hline Sritabutra \& Soonwera, 2013, Thailand & Not described & Not described \\
\hline Elango et al., 2010, India & Not described & Not described \\
\hline $\begin{array}{l}\text { Santamaría, Cabrera, Zipa, \& Pardo, 2012, } \\
\text { Colombia }\end{array}$ & 2 months & Not described \\
\hline $\begin{array}{l}\text { Govere, Durrheim, Baker, Hunt, \& Coetzee, 2000, } \\
\text { Johannesburg }\end{array}$ & Not described & Not described \\
\hline Govindarajan \& Sivakumar, 2012, India & Not described & Not described \\
\hline Hadis, Lulu, Mekonnen, \& Asfaw, 2003, Ethiopia & 1 month & $\begin{array}{l}\text { Variation in mosquito species and different methods for } \\
\text { obtaining essential oils }\end{array}$ \\
\hline Murugan et al., 2012, India & Not described & Not described \\
\hline Karunamoorthi, Ilango, \& Murugan, 2010, India & Not described & Not described \\
\hline $\begin{array}{l}\text { Keziah, Nukenine, Danga, Younoussa, \& Esimone, } \\
\text { 2015, Nigeria }\end{array}$ & 3 weeks & Not described \\
\hline Soonwera \& Phasomkusolsil, 2015, Thailand & Not described & Not described \\
\hline Sajo et al., 2015, Nepal & 6 days & Not described \\
\hline Misni, Sulaiman, Othman, \& Omar, 2009, Malaysia & Not described & $\begin{array}{l}\text { Different mosquito species and not standardized testing } \\
\text { protocols }\end{array}$ \\
\hline $\begin{array}{l}\text { Moore, Darling, Sihuincha, Padilla, \& Devine, 2007, } \\
\text { Guatemala and Peru }\end{array}$ & 34 days & Not described \\
\hline Rajan, Hein, Porte, \& Wikel, 2005, EUA & Not described & Not described \\
\hline Choochote et al, 2007, Thailand & Not described & Not described \\
\hline
\end{tabular}

Source: Own Authorship. 
Table 3. Standardization of the herbal medicinal products evaluated in this systematic review.

\begin{tabular}{|c|c|c|c|c|c|}
\hline $\begin{array}{l}\text { Author's name, year, } \\
\text { research country }\end{array}$ & Species & Vegetable drug & $\begin{array}{l}\text { Herbal } \\
\text { product }\end{array}$ & Standardization & Pharmaceutical form \\
\hline $\begin{array}{l}\text { Hill, Lenglet, Arnez, \& } \\
\text { Carneiro, 2007, Bolivia }\end{array}$ & $\begin{array}{l}\text { Eucalyptus maculata } \\
\text { citriodon }\end{array}$ & Not described & Essential oil & $\begin{array}{l}p \text {-mentan-3,8-diol } \\
\text { (PMD) } 30 \%\end{array}$ & Not described \\
\hline $\begin{array}{l}\text { Abagli, Alavo, Avlessi, \& } \\
\text { Moudachirou, 2012, Benin }\end{array}$ & Hyptis suaveolens & Leaves & Essential oil & Not described & Solution \\
\hline $\begin{array}{l}\text { Sritabutra \& Soonwera, } \\
\text { 2013, Thailand }\end{array}$ & Cymbopogon nardus* & Aerial parts & Essential oil & Not described & Solution \\
\hline Elango et al., 2010, India & Cocculus hirsutus** & Leaves & Crude extract & Not described & Suspension \\
\hline $\begin{array}{l}\text { Santamaría, Cabrera, Zipa, } \\
\text { \& Pardo, 2012, Colombia }\end{array}$ & $\begin{array}{l}\text { Corymbia citriodora and } \\
\text { Cymbopogon citratus }\end{array}$ & Leaves & Essential oil & Not described & Not described \\
\hline $\begin{array}{l}\text { Govere, Durrheim, Baker, } \\
\text { Hunt, \& Coetzee, 2000, } \\
\text { Johannesburg }\end{array}$ & $\begin{array}{c}\text { Eucalyptus maculata } \\
\text { citrodon }\end{array}$ & Not described & Not described & PMD 0.574/0.8 (p/p) & Lotion \\
\hline $\begin{array}{ll}\text { Govindarajan } & \& \\
\text { Sivakumar, 2012, India } & \end{array}$ & $\begin{array}{l}\text { Eclipta alba and } \\
\text { Andrographis } \\
\text { paniculata }\end{array}$ & Leaves & Crude extract & Not described & Solution \\
\hline $\begin{array}{l}\text { Hadis, Lulu, Mekonnen, \& } \\
\text { Asfaw, 2003, Ethiopia }\end{array}$ & Ruta chalepensis*** & Aerial parts & Essential oil & Not described & Solution \\
\hline Murugan et al., 2012, India & Citrus sinensis & Aerial parts & Crude extract & Not described & Suspension \\
\hline $\begin{array}{l}\text { Karunamoorthi, Ilango, \& } \\
\text { Murugan, 2010, India }\end{array}$ & Cymbopogon citratus & Leaves & Crude extract & Not described & Not described \\
\hline $\begin{array}{l}\text { Keziah, Nukenine, Danga, } \\
\text { Younoussa, \& Esimone, } \\
\text { 2015, Nigeria }\end{array}$ & $\begin{array}{l}\text { Ocimum gratissimum } \mathrm{L} . \\
\text { and Lantana camara }\end{array}$ & Leaves & Crude extract & Not described & Cream \\
\hline $\begin{array}{lr}\text { Soonwera } & \& \\
\text { Phasomkusolsil, } & 2015, \\
\text { Thailand } & \end{array}$ & $\begin{array}{l}\text { Cymbopogon citratus e } \\
\text { Cananga odorata }\end{array}$ & Aerial parts & Essential oil & Not described & Solution \\
\hline Sajo et al., 2015, Nepal & Cymbopogon winteratus & Leaves & Essential oil & Not described & Not described \\
\hline $\begin{array}{l}\text { Misni, Sulaiman, Othman, } \\
\text { \& Omar, 2009, Malaysia }\end{array}$ & Piper aduncum & Leaves & Essential oil & Not described & Solution \\
\hline $\begin{array}{l}\text { Moore, Darling, Sihuincha, } \\
\text { Padilla, \& Devine, 2007, } \\
\text { Guatemala and Peru }\end{array}$ & $\begin{array}{l}\text { Corymbia citriodora and } \\
\text { Cymbopogon citratus }\end{array}$ & Not described & Essential oil & Not described & Solution \\
\hline $\begin{array}{l}\text { Rajan, Hein, Porte, \& } \\
\text { Wikel, 2005, EUA }\end{array}$ & Allium sativum & Bulb & Not described & Not described & Capsule \\
\hline $\begin{array}{l}\text { Choochote et al, 2007, } \\
\text { Thailand }\end{array}$ & $\begin{array}{l}\text { Curcuma zedoaria } \\
\text { Roscoe } * * * *\end{array}$ & Aerial parts & Essential oil & Not described & Solution \\
\hline
\end{tabular}

*C. odorata Hook., Syzygium aromaticum, Z. officinale Roscoe, Cymbopogon citratus, Cymbopogon nardus, Eucalyptus citriodara Hook, Citrus reticulata, and Ocimum basilicum.

**Aegle marmelos, Andrographis lineate, Andrographis paniculata, Eclipta prostrata, andTagetes erecta

*** Azidirachta indica, Chrysanthemum cineraraiefolium, Ruta chalepensis, and Eucalyptus maculata citriodora

**** Amomum xanthioides, Curcuma zedoaria Roscoe, Kaempferia galanga L, Anethum graveolens L, Apium graveolens L., Carum carvi L, Foeniculum vulgare, Piper longum L, Zanthoxylum limonella and Zanthoxylum piperitum (L.) DC. Source: Own Authorship.

\section{Discussion}

According to the World Health Organization, vector-borne diseases account for more than $17 \%$ of all infectious diseases, causing more than 700,000 deaths annually. Diseases such as malaria, dengue, schistosomiasis, African human trypanosomiasis, leishmaniasis, Chagas disease, yellow fever, Japanese encephalitis, and onchocerciasis are among the main vector-borne diseases (WHO, 2020).

Due to the burden of these diseases, chronic suffering, disability, and morbidity throughout life, the WHO elaborated the "Global Vector Control Response (GVCR) 2017-2030", which provides strategic guidance for urgent strengthening of vector control to prevent disease and respond to outbreaks. Among the recommendations are the development and evaluation 
of new tools, technologies, and approaches for vector-borne diseases, including disease control and management technologies (WHO, 2017).

In this context, the field of study of medicinal plants as repellents is important, since repellents must be safe, agreeable, and ecologically sustainable. Moreover, the cost of the production of repellents is another significant factor that corroborates to the development of research on flora.

\section{Discussion of Articles found in the search}

Essential Oils (EO) are complex mixtures of volatile organic compounds such as terpenes, sesquiterpenes, alcohols, esters, aldehydes, ketones, lactones, phenols, and phenol eters (Guenther, 1972; Nerio et al., 2010). In this review, most studies were performed with plants rich in essential oils. The studies of Choochote et al. (2007), Hadis et al., (2003); Sritabutra and Soonwera (2013), evaluated the efficacy of essential oils in more than one medicinal plant species.

Hadis et al. (2003) evaluated the repellent activity of essential oils of Eucalyptus maculata citriodon, Ruta chalepensis, Chrysanthemum cinerariaefolium, and Azadiracta indica. In this study, all medicinal plants showed repellent activity at different concentrations $(40 \%, 50 \%$, and $75 \%$ ). A possible explanation could be due to the variation of species in the mosquito population during the tests at different concentrations. The variation of species composition during the tests, may have affected the result of increasing protection by increasing or decreasing the number of sensitive or tolerant species of mosquitoes. Eucalyptus maculata citriodon oil gave a protection equivalent to that of $\mathrm{N}$-diethyl-m-toluamide (DEET) in identical concentrations. This result is important given the increased resistance to this repellent, caused by mutations in the vectors. DEET is the most common ingredient in mosquito repellents which is considered to act by inhibiting acetylcholinesterase in mosquitoes. Stanczyk et al. (2010) identified females of Aedes aegypti insensitive to DEET as a result of a genetically altered dominant trait.

Choochote et al. (2007) evaluated ten essential oils extracted from medicinal plants, however, only Zanthoxylum piperitum, Anethum graveolens, and Kaempferia galanga exercised protection against A. aegypti, with an average complete protection time of $1 \mathrm{~h}, 0.5 \mathrm{~h}$, and $0.25 \mathrm{~h}$, respectively. The highest potential was established from Z piperitum oil $+10 \%$ vanillin $(2.5 \mathrm{~h}$, range $=1-2.5 \mathrm{~h})$. This was probably due to the lower rate of evaporation and the greater persistence in the skin of vegetable products after the addition of vanillin. According to Raveau et al. (2020), the volatile nature and instability of the EOs components are the primary causes of EOs degradation.

Sritabutra e Soonwera (2013) evaluated the repellency effect of several herbal oils against medically important mosquitoes. The results demonstrated that clove oil, citronella oil, and lemongrass oil had high potency to control Aedes aegypt, and Culex quinquefasciatus. The phytochemical constituent of clove and citronella oil such as eugenol, citronellol, geraniol, citral, and limonen has pharmacological properties for mosquito repellent activity (Kang et al., 2009; Maia \& Moore, 2011; Shapiro, 2012). Despite the positive results, the oil repellency when compared to the positive control (KorYor $15 ®$ ) exhibited a shorter repellency time.

Studies by Hill et al. (2007), Misni et al. (2009), Abagli et al. (2012), Sajo et al. (2015), evaluated the species Eucalyptus maculata citriodon, Hyptis suaveolens, Cymbopogon winteratus, Piper aduncum. All the EOs of the analyzed species presented repellence, presenting better results in higher concentrations. However, when compared to the positive control group, the EOs had a lower repellency time. Hill et al. (2007) study showed an equal time of repellency, only when associating the EO with the positive control group (N,N-Dietil-m-toluamida - DEET). The ingredient is recommended as the positive control (usually $20 \%$ in ethanol) against which the effectiveness of alternative mosquito repellents is judged (WHO, 2009). 


\section{Evaluation of repellent activity and quality of products used}

Although studies have shown the effectiveness of herbal repellent products, when applied to the skin, the protection provided usually dissipates rapidly (Trongtokit et al., 2005; Li et al., 2013;). In the case of essential oils, this fact is related to high volatility, a property that may be enhanced with the development of formulations that could be able to keep the principles active for an extended period. Considering the high volatility of EO, repellent performance is heavily dependent on the product's composition and capacity to prolong the duration of action. According to Oliveira et al, 2020, formulations based on creams, polymers, mixtures, or controlled-release microcapsules provide better results in repellency.

According to a study by Choocote et al. (2007) assessed in this review, a compound combined with essential oil that was demonstrated to increase repellency time was vanillin. Additionally, the repellency time of pure oil was shorter when compared with the mixture of $10 \%$ vanillin. Keziah et al., (2012) analyzed the formulation of crème with crude extract of leaves Ocimum gratissimum and Lantana camara L. which presented repellent activity against Aedes aegypti L., without exhibiting adverse reactions in the volunteers. Therefore, fixing additives and the production of repellents combined are possibilities that can increase the effectiveness and economic value of essential oils with repellent activity.

The process of transforming a plant into a medicine must adhere to established norms to ensure the plant's chemical and pharmacological integrity, ensuring consistent biological action and user safety. (Han et al.,2019). When analyzing the articles in this study, there are a significant number of limitations and absences, where most of the articles did not present the characteristics of medicinal plants in the tests and there was hardly any standardization of their products according to their chemical markers, there was also scarce descriptions of qualitative and quantitative quality control tests (only two articles presented). Such absences will interfere with the quality of the articles as well as question the safety and efficacy of the final product.

In the present study, only two articles, Hill et al. (2007) and Govere et al. (2000), described a standardization of the repellent product based on a biomarker. The substance used as a marker was p-mentan-3,8-diol (PMD), an essential oil classified as monoterpene and that can be extracted from aromatic plants such as eucalyptus (Corymbia citriodora) and has proven insect repellent properties similar to DEET (Carroll \& Loye, 2006).

Despite the findings, there are some difficulties inherent to the development of the herbal product, due to the complexity of the plant's constituents,the raw material, and the variability in the quality of the products obtained from the same plant species. These characteristics are related to the factors and conditions of the place of cultivation, the procedure of collection, handling, and processing of the vegetable raw material. Thereby, plant products will show variations, further increasing the requirement for standardization to guarantee efficacy, safety, and quality (Liu et al., 2018).

The standardization and quality control of herbal medicines is carried out based on the content of biomarker, which by definition is a substance or a group of them, which is present mainly in a certain plant species and is the responsible or one of those responsible for the plant's pharmacological activity. Additionally, biomarkers must be stable and capable of analysis by analytical and bioanalytical processes, must guarantee the results' reliability, and must be validated according to current legislation. Hence, the biomarker's presence in an appropriate quantity demonstrates that the other components will be equally represented allowing the reproducibility of new studies with the same plant. Therefore, biomarkers are indispensable requirements in the production of medicines, in the planning and monitoring of technological production, and for studies on the stability of intermediate and final products. Thus, standardization is a prerequisite for constant therapeutic effects and patient safety (Han et al., 2019; Liu et al., 2018).

From this perspective of standardizing a product of plant origin, only two executable works are standardization and quality control tests of the obtained products, and most of these works may have carried out these tests. This statement can be 
observed in Table 4, which presents findings in the literature on experiments for the identification and analysis of plant biomarkers that were used in the studies. Also in this table, the main compounds of the plants used in the studies are from the class of essential oils and the most used method was Gas Chromatography coupled with Mass Spectrometry (CG-MS). This fact is justified by the aromatic and low molecular weight which are characteristics of the main biomarkers present in the medicinal species analyzed (Adams, 2007).

Table 4 - Majority Compounds Described in the Literature of the Plants Selected for Review.

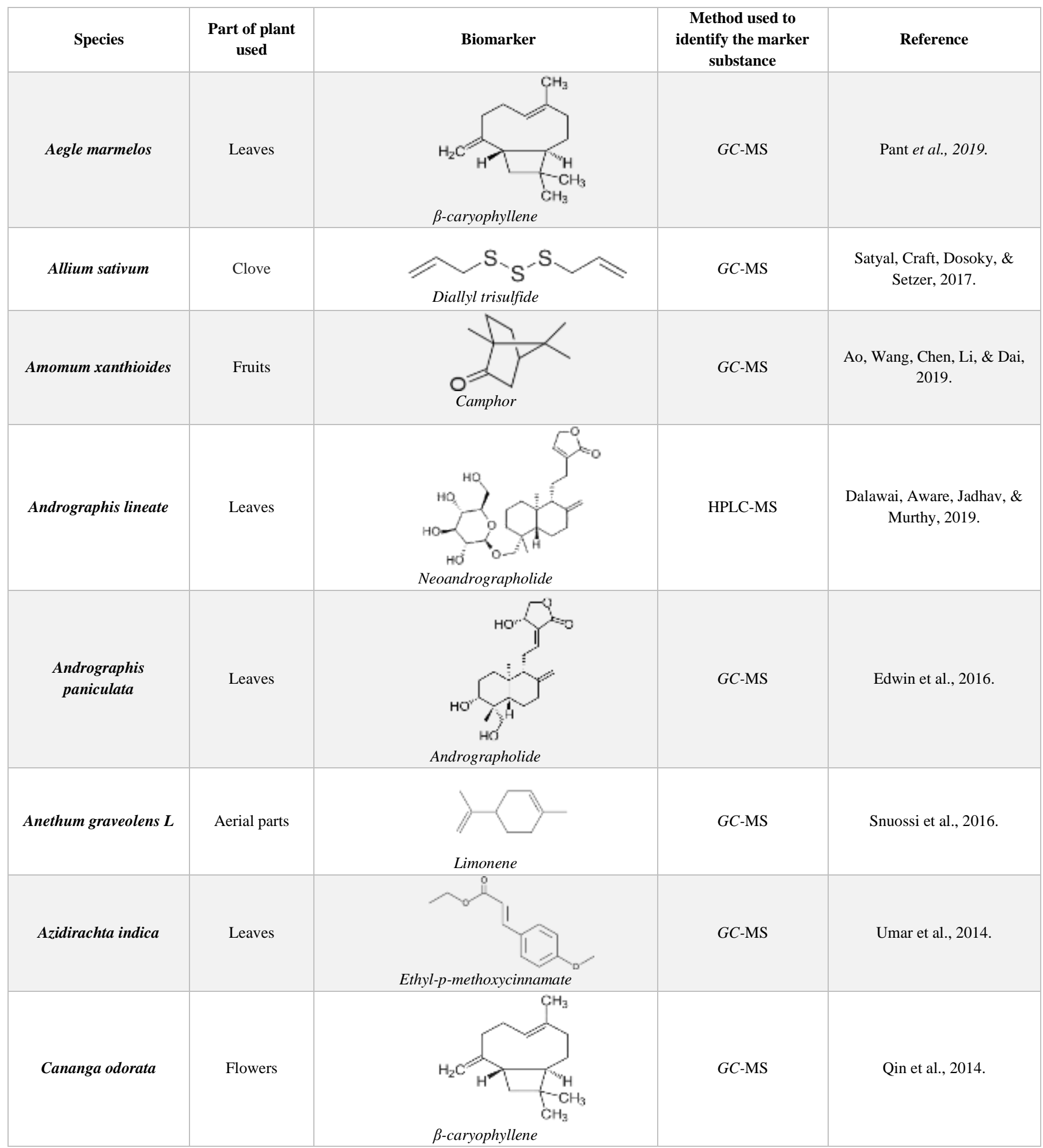


Research, Society and Development, v. 11, n. 1, e2611124142, 2022

(CC BY 4.0) | ISSN 2525-3409 | DOI: http://dx.doi.org/10.33448/rsd-v11i1.24142

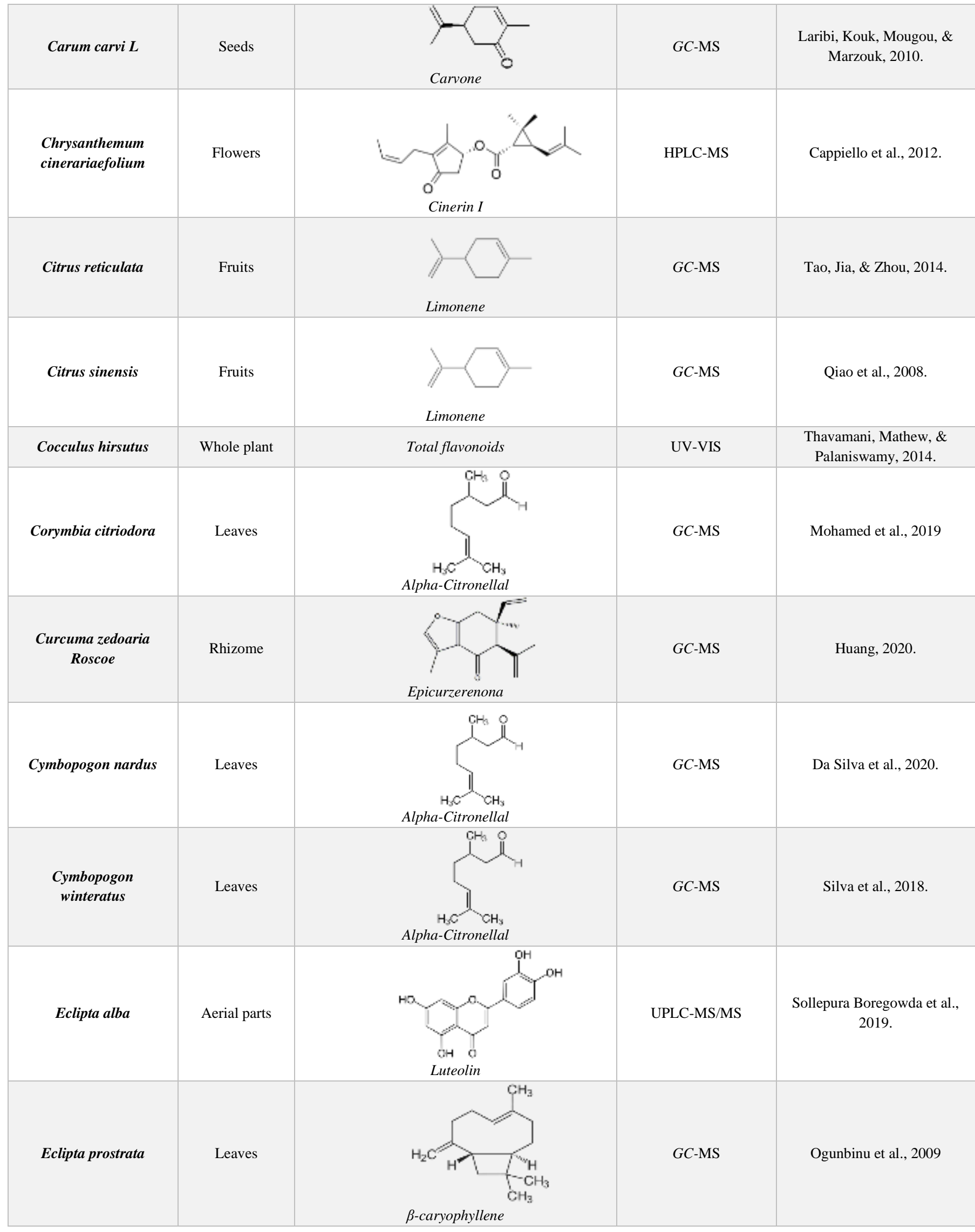


Research, Society and Development, v. 11, n. 1, e2611124142, 2022

(CC BY 4.0) | ISSN 2525-3409 | DOI: http://dx.doi.org/10.33448/rsd-v11i1.24142

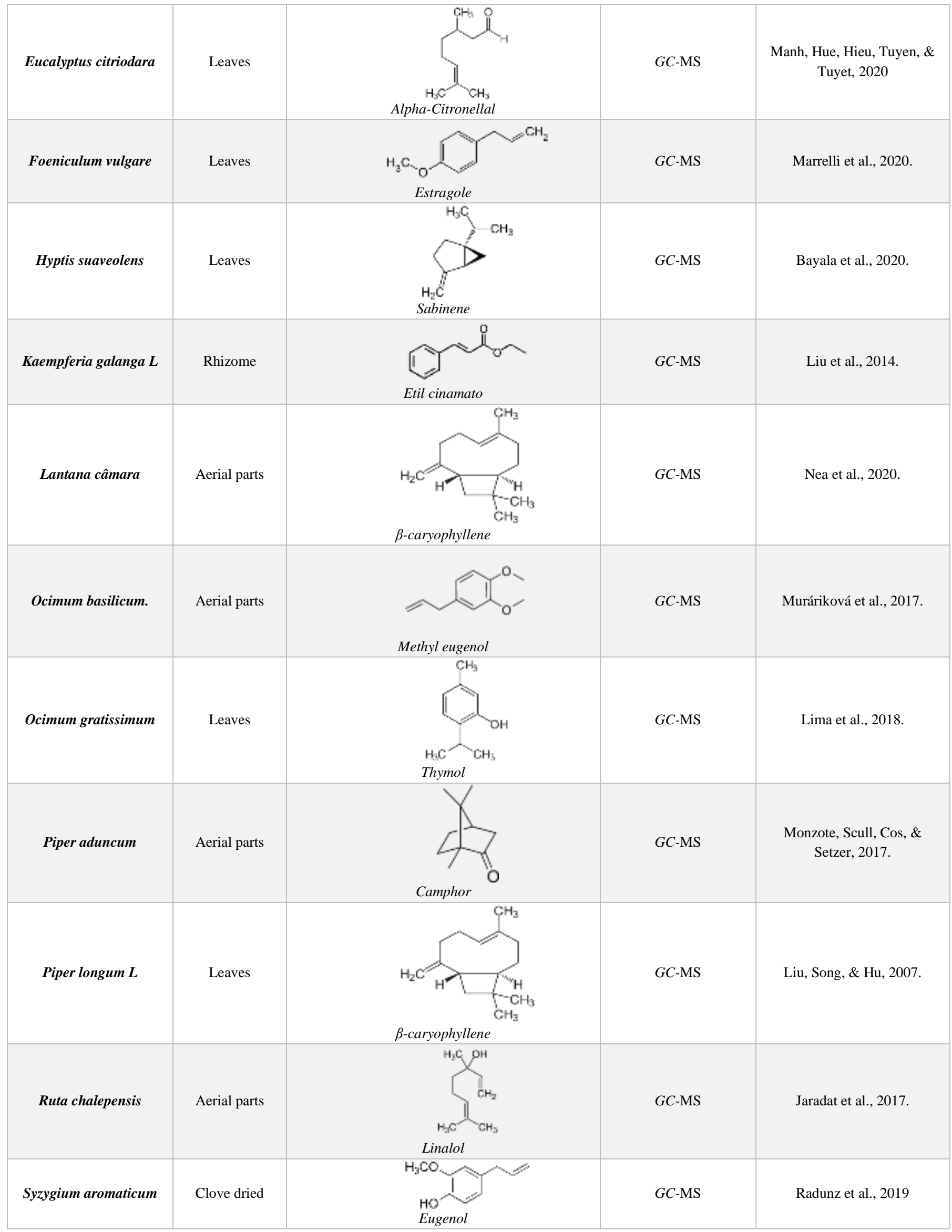




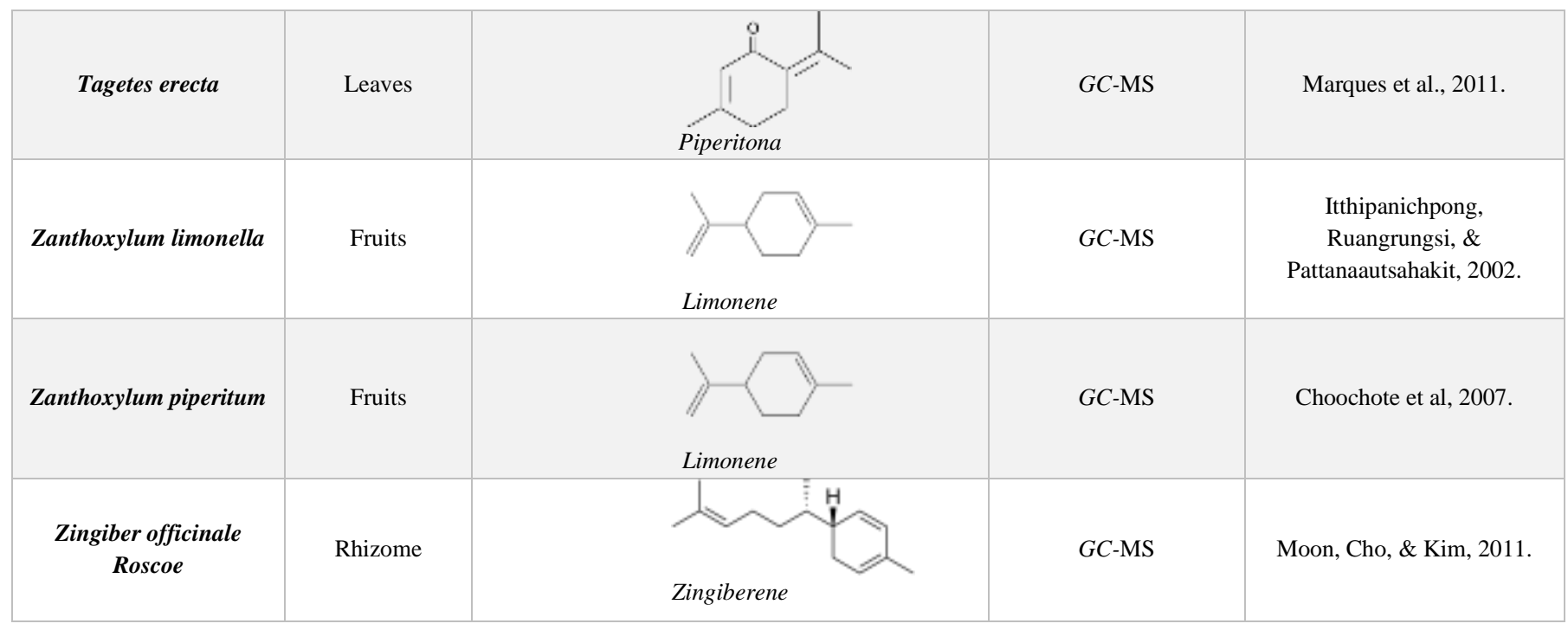

*GC-MS - Gas Chromatography Coupled to the Mass Spectrometer; **HPLC-MS - High-Efficiency Liquid Chromatography Coupled with Mass Spectrometer; ***UPLC-MS/MS - Ultra Performance Liquid Chromatography Coupled with Tandem Mass Spectrometry; ****UVVIS - Ultraviolet-Visible Spectrophotometry. Source: Own Authorship.

\section{Evaluation of clinical trials of medicinal plants with repellent activity}

Several methods were used to assess mosquito repellent activity by the studies that were included in this review, mostly amounts of EO or extracts were previously dissolved in a fixed volume of solvent and applied evenly to arms, legs, mosquito nets, or cages. To calculate the percentage of repellency, most studies evaluated the number of mosquito bites at certain times, the number of mosquitoes that landed and the time elapsed until the first bite on the arm or lower limbs.

Due to the variability in the methodologies found in the tests to assess repellency (different conditions, variables, and parameters), comparisons between the results of different clinical trials are not possible. Consequently, the results can only be compared with positive or negative control, in the same clinical trial, in order to classify the degree of repellency.

In this context, effective assessment is necessary following the adaptation of the CONSORT instrument (Table 5) for clinical trials with medicinal plants, since it allows the assessment of various aspects that interfere with the transparency of the study report with medicinal herbs. Many studies did not describe some methods (purity tests, biomarker standardization) and who performed them (e.g.name of the laboratory). Furthermore, they also failed to inform whether a product sample (eg, retention sample) was kept and, if so, where it was kept or deposited.

The standardized extracts were of high quality containing consistent levels of compounds, submitted to rigorous control. The analysis of the chemical profile is essential since using the appropriate techniques can provide a precise report of its constituents, besides providing qualitative and quantitative information (Folashade, Omoregie, \& Ochogu, 2012). In view of the fact that the studies do not report the sample calculation and the size of the sample, these studies may be speculated to have small chances of being statistically significant (Sakpal, 2010).

The World Health Organization Guidelines for testing the efficacy of mosquito repellents for human skin (2009), recommends that the method of choice be performed in humans for producing results relevant to the conditions of use. In this review, the study by Hill et al., (2007), endorsed Eucalyptus maculata citriodon with p-menthane 3.8 diol (PMD), applied in mosquito nets making the evaluation of the product's repellency efficacy not possible. 
Table 5. Evaluation of the clinical trials of medicinal plants according to recommendations from PRISMA (Main Items for Reporting Systematic Reviews and Meta-analyzes) statement.

\begin{tabular}{|c|c|}
\hline $\begin{array}{l}\text { Author's name, year and } \\
\text { research country }\end{array}$ & Research limitations \\
\hline $\begin{array}{l}\text { Govere, Durrheim, Baker, } \\
\text { Hunt, \& Coetzee, } 2000\end{array}$ & $\begin{array}{l}\text { Characteristics of the medicinal plant (botanical identity), concentration of extraction solvent used, } \\
\text { standardization (quantity of active constituents/chemical marker per dosage unit form) of the herbal } \\
\text { product, and description of the qualitative and purity tests }\end{array}$ \\
\hline $\begin{array}{l}\text { Hadis, Lulu, Mekonnen, } \\
\text { \& Asfaw, } 2003\end{array}$ & $\begin{array}{l}\text { Characteristics of the medicinal plant (botanical identity), concentration of extraction solvent used, } \\
\text { standardization (quantity of active constituents/chemical marker per dosage unit form) of the herbal } \\
\text { product, and description of the qualitative and purity tests }\end{array}$ \\
\hline $\begin{array}{l}\text { Rajan, Hein, Porte, \& } \\
\text { Wikel, } 2005\end{array}$ & $\begin{array}{l}\text { Characteristics of the medicinal plant (license in the country in which the study was conducted), } \\
\text { standardization (quantity of active constituents/chemical marker per dosage unit form) of the herbal } \\
\text { product, and description of the qualitative and purity tests }\end{array}$ \\
\hline Choochote et al., 2007 & Description of the purity tests \\
\hline $\begin{array}{l}\text { Moore, Darling, } \\
\text { Sihuincha, Padilla, \& } \\
\text { Devine, } 2007\end{array}$ & Description of the qualitative and purity tests \\
\hline $\begin{array}{l}\text { Hill, Lenglet, Arnez, \& } \\
\quad \text { Carneiro, } 2007\end{array}$ & $\begin{array}{l}\text { Characteristics of the medicinal plant (botanical identity), standardization (quantity of active } \\
\text { constituents/chemical marker per dosage unit form) of the herbal product, and description of the } \\
\text { qualitative and purity tests }\end{array}$ \\
\hline $\begin{array}{l}\text { Misni, Sulaiman, Othman, } \\
\quad \text { \& Omar, } 2009\end{array}$ & $\begin{array}{l}\text { Standardization (quantity of active constituents/chemical marker per dosage unit form) of the herbal } \\
\text { product, and description of the qualitative and purity tests }\end{array}$ \\
\hline $\begin{array}{l}\text { Karunamoorthi, Ilango, \& } \\
\quad \text { Murugan, } 2010\end{array}$ & $\begin{array}{l}\text { Characteristics of the medicinal plant (botanical identity), standardization (quantity of active } \\
\text { constituents/chemical marker per dosage unit form) of the herbal product, and description of the } \\
\text { qualitative and purity tests }\end{array}$ \\
\hline Elango et al., 2010 & $\begin{array}{l}\text { Standardization (quantity of active constituents/chemical marker per dosage unit form) of the herbal } \\
\text { product, and description of the qualitative and purity tests }\end{array}$ \\
\hline Murugan et al., 2012 & $\begin{array}{l}\text { Characteristics of the medicinal plant (botanical identity), standardization (quantity of active } \\
\text { constituents/chemical marker per dosage unit form) of the herbal product, and description of the } \\
\text { qualitative and purity tests }\end{array}$ \\
\hline $\begin{array}{l}\text { Abagli, Alavo, Avlessi, \& } \\
\text { Moudachirou, } 2012\end{array}$ & $\begin{array}{l}\text { Characteristics of the medicinal plant (botanical identity), standardization (quantity of active } \\
\text { constituents/chemical marker per dosage unit form) of the herbal product, and description of the } \\
\text { qualitative and purity tests }\end{array}$ \\
\hline $\begin{array}{l}\text { Santamaría, Cabrera, } \\
\text { Zipa, \& Pardo, } 2012\end{array}$ & $\begin{array}{l}\text { Characteristics of the medicinal plant (botanical identity), dosage regimen and standardization (quantity } \\
\text { of active constituents/chemical marker per dosage unit form) of the herbal product, and description of } \\
\text { the qualitative and purity tests }\end{array}$ \\
\hline $\begin{array}{l}\text { Govindarajan \& } \\
\text { Sivakumar, } 2012\end{array}$ & $\begin{array}{l}\text { standardization (quantity of active constituents/chemical marker per dosage unit form) of the herbal } \\
\text { product, and description of the qualitative and purity tests }\end{array}$ \\
\hline $\begin{array}{l}\text { Sritabutra \& Soonwera, } \\
\qquad 2013\end{array}$ & $\begin{array}{l}\text { Characteristics of the medicinal plant (botanical identity), standardization (quantity of active } \\
\text { constituents/chemical marker per dosage unit form) of the herbal product, and description of the } \\
\text { qualitative and purity tests }\end{array}$ \\
\hline $\begin{array}{l}\text { Keziah, Nukenine, Danga, } \\
\text { Younoussa, \& Esimone, } \\
\qquad 2015\end{array}$ & $\begin{array}{l}\text { Standardization (quantity of active constituents/chemical marker per dosage unit form) of the herbal } \\
\text { product, and description of the qualitative and purity tests }\end{array}$ \\
\hline $\begin{array}{c}\text { Soonwera \& } \\
\text { Phansomkusolsil, } 2015\end{array}$ & $\begin{array}{l}\text { Characteristics of the medicinal plant (botanical identity), standardization (quantity of active } \\
\text { constituents/chemical marker per dosage unit form) of the herbal product, and description of the } \\
\text { qualitative and purity tests }\end{array}$ \\
\hline Sajo et al., 2013 & $\begin{array}{l}\text { Characteristics of the medicinal plant (botanical identity), concentration of extraction solvent used, } \\
\text { standardization (quantity of active constituents/chemical marker per dosage unit form) of the herbal } \\
\text { product, and description of the qualitative and purity tests }\end{array}$ \\
\hline
\end{tabular}




\section{Conclusion}

Most studies included in this review were of medicinal plants rich in essential oils which demonstrated good repellent activity against several species of mosquitoes, however due to the high volatility of these compounds, the protection time is reduced when compared to positive control. Therefore, despite these products' potential, the development and standardization of products that increase the repellency time are required to improve mosquito repellent efficiency.

The absence of standardization of the methodologies was an obstacle to the evaluation of the articles included in this review. As a result, a standardized protocol capable of comprehensively evaluating the quality of clinical trials of medicinal plants with mosquito repellent activity is recommended. We hope that this review will contribute to future studies of medicinal plants with repellent activity, given the great necessity for new products to prevent diseases transmitted by mosquitoes.

\section{References}

Abagli, A. Z., Alavo, T. B., Avlessi, F., \& Moudachirou, M. (2012). Potential of the bush mint, Hyptis suaveolens essential oil for personal protection against mosquito biting. Journal of the American Mosquito Control Association, 28(1), 15-19. https://doi.org/10.2987/11-6181.1

Adams, R. P. (2007). Identification of essential oil components by gas chromatography/mass spectrometry (Vol. 456). Carol Stream, IL: Allured publishing corporation.

Ali, M. S., Ravikumar, S., \& Beula, J. M. (2012). Bioactivity of seagrass against the dengue fever mosquito Aedes aegypti larvae. Asian Pacific journal of tropical biomedicine, 2(7), 570-573. https://doi.org/10.1016/S2221-1691(12)60099-9

Ao, H., Wang, J., Chen, L., Li, S., \& Dai, C. (2019). Comparison of volatile oil between the fruits of Amomum villosum Lour. and Amomum villosum Lour. var. xanthioides TL Wu et Senjen based on GC-MS and chemometric techniques. Molecules, 24(9), 1663. doi:10.3390/molecules24091663

Bayala, B., Nadembega, C., Guenné, S., Buñay, J., Zohoncon, M., Djigma, W., ... \& Simpore, J. (2020). Chemical Composition, Antioxidant and Cytotoxic Activities of Hyptis suaveolens (L.) Poit. Essential Oil on Prostate and Cervical Cancers Cells. Pakistan Journal of Biological Sciences: PJBS, 23(9), 11841192. 10.3923/pjbs.2020.1184.1192.

Booth, A., Clarke, M., Dooley, G., Ghersi, D., Moher, D., Petticrew, M., \& Stewart, L. (2012). The nuts and bolts of PROSPERO: an international prospective register of systematic reviews. Systematic reviews, 1(1), 1-9. 10.1186/2046-4053-1-2.

Cappiello, A., Tirillini, B., Famiglini, G., Trufelli, H., Termopoli, V., \& Flender, C. (2012). Determination of Natural Pyrethrins by Liquid Chromatography-Electron Ionisation-Mass Spectrometry. Phytochemical Analysis, 23(3), 191-196. https://doi.org/10.1002/pca.1342

Carroll, S. P., \& Loye, J. (2006). PMD, a registered botanical mosquito repellent with deet-like efficacy. Journal of the American Mosquito Control Association, 22(3), 507-514. https://doi.org/10.2987/8756-971X(2006)22[507:PARBMR]2.0.CO;2

Choochote, W., Chaithong, U., Kamsuk, K., Jitpakdi, A., Tippawangkosol, P., Tuetun, B. \& Pitasawat, B. (2007). Repellent activity of selected essential oils against Aedes aegypti. Fitoterapia, 78(5), 359-364. https://doi.org/10.1016/j.fitote.2007.02.006.

da Silva, L. C., de Souza Perinotto, W. M., Sá, F. A., de Souza, M. A. A., Bitencourt, R. D. O. B., Sanavria, A., ... \& da Costa Angelo, I. (2020). In vitro acaricidal activity of Cymbopogon citratus, Cymbopogon nardus and Mentha arvensis against Rhipicephalus microplus (Acari: Ixodidae). Experimental Parasitology, 216, 107937. 10.1016/j.exppara.2020.107937.

Dalawai, D., Aware, C., Jadhav, J. P., \& Murthy, H. N. (2019). RP-HPLC analysis of diterpene lactones in leaves and stem of different species of Andrographis. Natural Product Research, 1-4. 10.1080/14786419.2019.1662004

Deletre, E., Martin, T., Duménil, C., \& Chandre, F. (2019). Insecticide resistance modifies mosquito response to DEET and natural repellents. Parasites \& vectors, 12(1), 1-10. https://doi.org/10.1186/s13071-019-3343-9

Edwin, E. S., Vasantha-Srinivasan, P., Senthil-Nathan, S., Thanigaivel, A., Ponsankar, A., Pradeepa, V., ... \& Al-Dhabi, N. A. (2016). Anti-dengue efficacy of bioactive andrographolide from Andrographis paniculata (Lamiales: Acanthaceae) against the primary dengue vector Aedes aegypti (Diptera: Culicidae). Acta tropica, 163, 167-178. 10.1016/j.actatropica.2016.07.009

Elango, G., Rahuman, A. A., Zahir, A. A., Kamaraj, C., Bagavan, A., Rajakumar, G. \& Marimuthu, S. (2010). Evaluation of repellent properties of botanical extracts against Culex tritaeniorhynchus Giles (Diptera: Culicidae). Parasitology research, 107(3), 577-584. https://doi.org/10.1007/s00436-010-1897-8

Folashade, O., Omoregie, H., \& Ochogu, P. (2012). Standardization of herbal medicines-A review. International Journal of Biodiversity and Conservation, 4(3), 101-112. https://doi.org/10.5897/IJBC11.163

Gagnier, J. J., Boon, H., Rochon, P., Moher, D., Barnes, J., \& Bombardier, C. (2006). Reporting randomized, controlled trials of herbal interventions: an elaborated CONSORT statement. Annals of internal medicine, 144(5), 364-367. 10.7326/0003-4819-144-5-200603070-00013.

Geetha, R. V., \& Roy, A. (2014). Essential oil repellents-a short review. International Journal of Drug Development and Research, 6(2), $20-27$.

Ghosh, A., Chowdhury, N., \& Chandra, G. (2012). Plant extracts as potential mosquito larvicides. The Indian journal of medical research, 135(5), 581-598. 
Govere, J., Durrheim, D. N., Baker, L., Hunt, R., \& Coetzee, M. (2000). Efficacy of three insect repellents against the malaria vector Anopheles arabiensis. Medical and Veterinary Entomology, 14(4), 441-444. https://doi.org/10.1046/j.1365-2915.2000.00261.x

Guenther, E. (1972). The production of essential oils. The essential oils, 1, 87-226.

Hadis, M., Lulu, M., Mekonnen, Y., \& Asfaw, T. (2003). Field trials on the repellent activity of four plant products against mainly Mansonia population in western Ethiopia. Phytotherapy research, 17(3), 202-205. https://doi.org/10.1002/ptr.1051

Han, L., Wang, R., Zhang, X., Yu, X., Zhou, L., Song, T., ... \& Bai, C. (2019). Advances in processing and quality control of traditional chinese medicine Coptidis rhizoma (Huanglian): A Review. Journal of AOAC International, 102(3), 699-707. https://doi.org/10.5740/jaoacint.18-0303

Hill, N., Lenglet, A., Arnez, A. M., \& Carneiro, I. (2007). Plant based insect repellent and insecticide treated bed nets to protect against malaria in areas of early evening biting vectors: double blind randomised placebo controlled clinical trial in the Bolivian Amazon. BMJ, 335(7628), 1023. https://doi.org/10.1136/bmj.39356.574641.55

Huang, K. (2020) GC - MS Analysis of Volatile Components in Curcuma Zedoary [J]. Journal of Shaanxi University of Traditional Chinese Medicine, 01, 6975. 10.13424/j.cnki.jsctcm.2020.01.018.

Itthipanichpong, C., Ruangrungsi, N., \& Pattanaautsahakit, C. (2002). Chemical compositions and pharmacological effects of essential oil from the fruit of Zanthoxylum limonella. Journal of the Medical Association of Thailand = Chotmaihet Thangphaet, 85, S344-54.

Jaradat, N., Adwan, L., K'aibni, S., Zaid, A. N., Shtaya, M. J., Shraim, N., \& Assali, M. (2017). Variability of chemical compositions and antimicrobial and antioxidant activities of Ruta chalepensis leaf essential oils from three Palestinian regions. BioMed Research International, 2017. 10.1155/2017/2672689.

Kang, S. H., Kim, M. K., Seo, D. K., Noh, D. J., Yang, J. O., Yoon, C., \& Kim, G. H. (2009). Comparative repellency of essential oils against Culex pipiens pallens (Diptera: Culicidae). Journal of the Korean Society for Applied Biological Chemistry, 52(4), 353-359. https://doi.org/10.3839/jksabc.2009.063

Karunamoorthi, K., Ilango, K., \& Murugan, K. (2010). Laboratory evaluation of traditionally used plant-based insect repellent against the malaria vector Anopheles arabiensis Patton (Diptera: Culicidae). Parasitology research, 106(5), 1217-1223. https://doi.org/10.1007/s00436-010-1797-y

Keziah, E. A., Nukenine, E. N., Danga, S. P. Y., Younoussa, L., \& Esimone, C. O. (2015). Creams formulated with Ocimum gratissimum L. and Lantana camara L. crude extracts and fractions as mosquito repellents against Aedes aegypti L. (Diptera: Culicidae). Journal of Insect Science, 15(1). https://doi.org/10.1093/jisesa/iev025

Laribi, B., Kouki, K., Mougou, A., \& Marzouk, B. (2010). Fatty acid and essential oil composition of three Tunisian caraway (Carum carvi L.) seed ecotypes. Journal of the Science of Food and Agriculture, 90(3), 391-396. https://doi.org/10.1002/jsfa.3827

Li, Y., Kong, D., Huang, R., Liang, H., Xu, C., \& Wu, H. (2013). Variations in essential oil yields and compositions of Cinnamomum cassia leaves at different developmental stages. Industrial Crops and Products, 47, 92-101. 10.1016/j.indcrop.2013.02.031

Lima, A. S., Milhomem, M. N., Monteiro, O. S., Arruda, A. C. P., de Castro, J. A. M., Fernandes, Y. M. L., ... \& Costa-Junior, L. M. (2018). Seasonal analysis and acaricidal activity of the thymol-type essential oil of Ocimum gratissimum and its major constituents against Rhipicephalus microplus (Acari: Ixodidae). Parasitology Research, 117(1), 59-65. https://doi.org/10.1007/s00436-017-5662-0

Liu, C., Guo, D. A., \& Liu, L. (2018). Quality transitivity and traceability system of herbal medicine products based on quality markers. Phytomedicine, 44, 247-257. https://doi.org/10.1016/j.phymed.2018.03.006

Liu, L., Song, G., \& Hu, Y. (2007). GC-MS Analysis of the Essential Oils of Piper nigrum L. and Piper longum L. Chromatographia, 66(9), 785-790. $10.1365 / \mathrm{s} 10337-007-0408-2$

Liu, X. C., Liang, Y., Shi, W. P., Liu, Q. Z., Zhou, L., \& Liu, Z. L. (2014). Repellent and insecticidal effects of the essential oil of Kaempferia galanga rhizomes to Liposcelis bostrychophila (Psocoptera: Liposcelidae). Journal of Economic Entomology, 107(4), 1706-1712. 10.1603/ec13491.

Maia, M. F., \& Moore, S. J. (2011). Plant-based insect repellents: a review of their efficacy, development and testing. Malaria journal, 10(1), 1-15. https://doi.org/10.1186/1475-2875-10-S1-S11

Manh, H. D., Hue, D. T., Hieu, N. T. T., Tuyen, D. T. T., \& Tuyet, O. T. (2020). The Mosquito larvicidal activity of essential oils from Cymbopogon and Eucalyptus Species in Vietnam. Insects, 11(2), 128. 10.3390/insects11020128.

Marques, M. M., Morais, S. M., Vieira, Í. G., Vieira, M. G., Silva, A. R. A., De Almeida, R. R., \& Guedes, M. I. F. (2011). Larvicidal activity of Tagetes erecta against Aedes aegypti. Journal of the American Mosquito Control Association, 27(2), 156-158. 10.2987/10-6056.1.

Marrelli, M., Amodeo, V., Viscardi, F., De Luca, M., Statti, G., \& Conforti, F. (2020). Essential Oils of Foeniculum vulgare subsp. piperitum and Their in Vitro Anti-Arthritic Potential. Chemistry \& Biodiversity, 17(11), e2000388. https://doi.org/10.1002/cbdv.202000388

McHugh, M. L. (2012). Interrater reliability: the kappa statistic. Biochemia medica, 22(3), 276-282.

Misni, N., Sulaiman, S., Othman, H., \& Omar, B. (2009). Repellency of essential oil of Piper aduncum against Aedes albopictus in the laboratory. Journal of the American Mosquito Control Association, 25(4), 442-447. https://doi.org/10.2987/09-0006.1

Mohamed, A. A., Behiry, S. I., Younes, H. A., Ashmawy, N. A., Salem, M. Z. M., Márquez-Molina, O., \& Barbabosa-Pilego, A. (2019). Antibacterial activity of three essential oils and some monoterpenes against Ralstonia solanacearum phylotype II isolated from potato. Microbial Pathogenesis, 135 , 103604. https://doi.org/10.1016/j.micpath.2019.103604 
Moher, D., Liberati, A., Tetzlaff, J., Altman, D. G. (2009). The PRISMA Group Preferred Reporting Items for Systematic Reviews and Meta-Analyses: The PRISMA Statement. PLOS Medicine, 6(7), e1000097. https://doi.org/10.1371/journal.pmed.1000097

Monzote, L., Scull, R., Cos, P., \& Setzer, W. N. (2017). Essential oil from Piper aduncum: Chemical analysis, antimicrobial assessment, and literature review. Medicines, 4(3), 49. 10.3390/medicines4030049.

Moon, H. I., Cho, S. B., \& Kim, S. K. (2011). Retracted: Composition and immunotoxicity activity of essential oils from leaves of Zingiber officinale Roscoe against Aedes aegypti L. Immunopharmacology and immunotoxicology, 33(1), 201-204. 10.3109/08923973.2010.495393.

Moore, S. J., Darling, S. T., Sihuincha, M., Padilla, N., \& Devine, G. J. (2007). A low-cost repellent for malaria vectors in the Americas: results of two field trials in Guatemala and Peru. Malaria Journal, 6(1), 1-6. https://doi.org/10.1186/1475-2875-6-101

Muráriková, A., Ťažký, A., Neugebauerová, J., Planková, A., Jampílek, J., Mučaji, P., \& Mikuš, P. (2017). Characterization of essential oil composition in different basil species and pot cultures by a GC-MS method. Molecules, 22(7), 1221. https://doi.org/10.3390/molecules22071221

Murugan, K., Kumar, P. M., Kovendan, K., Amerasan, D., Subrmaniam, J., \& Hwang, J. S. (2012). Larvicidal, pupicidal, repellent and adulticidal activity of Citrus sinensis orange peel extract against Anopheles stephensi, Aedes aegypti and Culex quinquefasciatus (Diptera: Culicidae). Parasitology research, 111(4), 1757-1769. https://doi.org/10.1007/s00436-012-3021-8

Naseem, S., Malik, M. F., \& Munir, T. (2016). Mosquito management: A review. Journal of Entomology and Zoology Studies, 4(5), 73-79.

Nea, F., Kambiré, D. A., Genva, M., Tanoh, E. A., Wognin, E. L., Martin, H., ... \& Fauconnier, M. L. (2020). Composition, seasonal variation, and biological activities of Lantana camara essential oils from Côte d'Ivoire. Molecules, 25(10), 2400. https://doi.org/10.3390/molecules25102400

Nerio, L. S., Olivero-Verbel, J., \& Stashenko, E. (2010). Repellent activity of essential oils: a review. Bioresource technology, 101(1), 372-378. https://doi.org/10.1016/j.biortech.2009.07.048

Ogunbinu, A. O., Flamini, G., Cioni, P. L., Ogunwande, I. A., \& Okeniyi, S. O. (2009). Essential oil constituents of Eclipta prostrata (L.) L. and Vernonia amygdalina Delile. Natural Product Communications, 4(3), 421-424. https://doi.org/10.1177/1934578X0900400321

Pant, P., Sut, S., Castagliuolo, I., Gandin, V., Maggi, F., Gyawali, R., \& Dall'Acqua, S. (2019). Sesquiterpene rich essential oil from nepalese bael tree (Aegle marmelos (1.) correa) as potential antiproliferative agent. Fitoterapia, 138, 104266. https://doi.org/10.1016/j.fitote.2019.104266

Pohlit, A. M., Lopes, N. P., Gama, R. A., Tadei, W. P., \& Andrade Neto, V. F. D. (2011). Patent literature on mosquito repellent inventions which contain plant essential oils-a review. Volume 77, Número 6, Pags. 598-617. http://dx.doi.org/10.1055/s-0030-1270723

Qiao, Y., Xie, B. J., Zhang, Y., Zhang, Y., Fan, G., Yao, X. L., \& Pan, S. Y. (2008). Characterization of aroma active compounds in fruit juice and peel oil of Jinchen sweet orange fruit (Citrus sinensis (L.) Osbeck) by GC-MS and GC-O. Molecules, 13(6), 1333-1344. https://doi.org/10.3390/molecules13061333

Qin, X. W., Hao, C. Y., He, S. Z., Wu, G., Tan, L. H., Xu, F., \& Hu, R. S. (2014). Volatile organic compound emissions from different stages of Cananga odorata flower development. Molecules, 19(7), 8965-8980. doi:10.3390/molecules19078965

Radunz, M., Martins da Trindade, M. L., Camargo, T. M., Radunz, A. L., Borges, C. D., Gandra, E. A., \& Helbig, E. (2019). Antimicrobial and antioxidant activity of unencapsulated and encapsulated clove (Syzygium aromaticum, L.) essential oil. Food Chemistry, 276, 180-186. 10.1016/j.foodchem.2018.09.173.

Rajan, T. V., Hein, M., Porte, P., \& Wikel, S. (2005). A double-blinded, placebo-controlled trial of garlic as a mosquito repellant: a preliminary study. Medical and veterinary entomology, 19(1), 84-89.https://doi.org/10.1111/j.0269-283X.2005.00544.x

Raveau, R., Fontaine, J., \& Lounès-Hadj Sahraoui, A. (2020). Essential oils as potential alternative biocontrol products against plant pathogens and weeds: A review. Foods, 9(3), 365. https://doi.org/10.3390/foods9030365

Reiter, P. (2001). Climate change and mosquito-borne disease. Environmental health perspectives, 109(suppl 1), 141-161. https://doi.org/10.1289/ehp.01109s1141

Rueda, L.M (2008). Global diversity of mosquitoes (Insecta: Diptera: Culicidae) in freshwater. Hydrobiology, 595, 477-487. https://doi.org/10.1007/s10750007-9037-x

Sajo, M. V., Song, S. B., Bajgai, J., Kim, Y. J., Kim, P. S., Ahn, D. W., ... \& Lee, K. J. (2015). Applicability of citronella oil ('Cymbopogon winteratus') for the prevention of mosquito-borne diseases in the rural area of Tikapur, far-western Nepal. Rural and remote health, 15(4), 121

Sakpal, T. (2010). Sample size estimation in clinical trial. Perspectives in clinical research, 1(2), 67-67.

Sangwan, N. S., Farooqi, A. H. A., Shabih, F., \& Sangwan, R. S. (2001). Regulation of essential oil production in plants. Plant growth regulation, 34(1), 3-21. https://doi.org/10.1023/A:1013386921596

Santamaría, E., Cabrera, O. L., Zipa, Y., \& Pardo, R. H. (2012). Eficacia en campo de un repelente a base de para-mentano-3, 8-diol y aceite de limonaria contra Culicoides pachymerus (Diptera: Ceratopogonidae) en Colombia. Biomédica, 32(3), 457-460. http://dx.doi.org/10.7705/biomedica.v32i3.738.

Satyal, P., Craft, J. D., Dosoky, N. S., \& Setzer, W. N. (2017). The chemical compositions of the volatile oils of garlic (Allium sativum) and wild garlic (Allium vineale). Foods, 6(8), 63. https://doi.org/10.3390/foods6080063

Shapiro, R. (2012). Prevention of vector transmitted diseases with clove oil insect repellent. Journal of pediatric nursing, 27(4), 346-349. https://doi.org/10.1016/j.pedn.2011.03.011

Silva, C. T. S., Wanderley-Teixeira, V., Cunha, F. M., Oliveira, J. V., Dutra, K. A., Navarro, D. F., \& Teixeira, A. A. C. (2018). Effects of citronella oil (Cymbopogon winterianus Jowitt ex Bor) on Spodoptera frugiperda (JE Smith) midgut and fat body. Biotechnic \& Histochemistry, 93(1), 36-48. $10.1080 / 10520295.2017 .1379612$ 
Research, Society and Development, v. 11, n. 1, e2611124142, 2022

(CC BY 4.0) | ISSN 2525-3409 | DOI: http://dx.doi.org/10.33448/rsd-v11i1.24142

Snuossi, M., Trabelsi, N., Ben Taleb, S., Dehmeni, A., Flamini, G., \& De Feo, V. (2016). Laurus nobilis, Zingiber officinale and Anethum graveolens essential oils: composition, antioxidant and antibacterial activities against bacteria isolated from fish and shellfish. Molecules, 21(10), 1414. doi:10.3390/molecules21101414

Sollepura Boregowda, R., Murali, N., C Udayashankar, A., R Niranjana, S., S Lund, O., \& S Prakash, H. (2019). Antifungal Activity of Eclipta alba Metabolites against Sorghum Pathogens. Plants (Basel, Switzerland), 8(3), 72. https://doi.org/10.3390/plants8030072

Soonwera, M., \& Phasomkusolsil, S. (2015). Efficacy of Thai herbal essential oils as green repellent against mosquito vectors. Acta tropica, 142, 127-130. https://doi.org/10.1016/j.actatropica.2014.11.010

Sritabutra, D., \& Soonwera, M. (2013). Repellent activity of herbal essential oils against Aedes aegypti (Linn.) and Culex quinquefasciatus (Say.). Asian Pacific Journal of Tropical Disease, 3(4), 271-276. https://doi.org/10.1016/S2222-1808(13)60069-9

Stanczyk, N. M., Brookfield, J. F., Ignell, R., Logan, J. G., \& Field, L. M. (2010). Behavioral insensitivity to DEET in Aedes aegypti is a genetically determined trait residing in changes in sensillum function. Proceedings of the National Academy of Sciences, 107(19), 8575-8580.

Tao, N., Jia, L., \& Zhou, H. (2014). Anti-fungal activity of Citrus reticulata Blanco essential oil against Penicillium italicum and Penicillium digitatum. Food chemistry, 153, 265-271. https://doi.org/10.1016/j.foodchem.2013.12.070

Thavamani, B. S., Mathew, M., \& Palaniswamy, D. S. (2014). Anticancer activity of Cocculus hirsutus against Dalton's lymphoma ascites (DLA) cells in mice. Pharmaceutical biology, 52(7), 867-872. https://doi.org/10.3109/13880209.2013.871642.

Trongtokit, Y., Rongsriyam, Y., Komalamisra, N., \& Apiwathnasorn, C. (2005). Comparative repellency of 38 essential oils against mosquito bites. Phytotherapy Research: An International Journal Devoted to Pharmacological and Toxicological Evaluation of Natural Product Derivatives, 19(4), 303-309. https://doi.org/10.1002/ptr.1637

Umar, M. I., Asmawi, M. Z., Sadikun, A., Abdul Majid, A. M. S., Atangwho, I. J., Khadeer Ahamed, M. B., ... \& Ahmad, A. (2014). Multi-constituent synergism is responsible for anti-inflammatory effect of Azadirachta indica leaf extract. Pharmaceutical Biology, 52(11), 1411-1422. https://doi.org/10.3109/13880209.2014.895017

US EPA. 1999. "Citronella (Oil of Citronella) (021901) Fact Sheet.” 21901. RED Facts. Washington, DC: US EPA Office of Pesticides and Toxic Substances. https://www3.epa.gov/pesticides/chem_search/reg_actions/registration/fs_PC021901_01-Nov-99.pdf.

Varun, T., Ruchi, Y., Kumar, S. A., Vivek, T., Shweta, Y., Veer, V., \& Devanathan, S. (2013). Larvicidal activity of leaf extract of some weeds against malaria vector Anopheles stephensi. International journal of environmental research and public health, 1, 35-39.

Wilke, A. B. B., \& Marrelli, M. T. (2015). Paratransgenesis: a promising new strategy for mosquito vector control. Parasites \& Vectors, 8(1), 342, 1-9. https://doi.org/10.1186/s13071-015-0959-2

World Health Organization. (2009). Guidelines for efficacy testing of mosquito repellents for human skin (No. WHO/HTM/NTD/WHOPES/2009.4). World Health Organization.

World Health Organization. (2016). Cumulative Zika suspected and confirmed cases reported by countries and territories in the Americas, 2015 -2016.

World Health Organization. (2017). Global vector control response 2017-2030.

World Health Organization. (2020). Vector-borne diseases. https://www.who.int/news-room/fact-sheets/detail/vector-borne-diseases. 